краевъ фистулы съ стьнками таза настолько, что онъ могъ свободно приблшзить задній край фистулы къ переднему. Освъживъ затьмъ крал фистулы, онъ соединиль ихъ серебряными швами со стороны introitus vaginac. Спустя пва м'ьсяца больная выписалась съ полнымъ держаніемъ мочп.

Во второмь случа' в у больной A. L., принятой 23 марта 1891 г. можно было изъ влагалища свободно ввести два палыца въ мочевой пузырь. Фисту.а располагалась съ правой стороны возл'ь праваго края губ́б port. vag., цинчемъ съ правой стороны половина губт отсутствовала. 0ть верхушки фнету.ыт, расположенной приблизительно на высоть внутренняго зьва края фистулы расходились въ видњ треугольника съ широкимь основаніемъ кнаружи, кверху и кзади къ стьнкамъ таза, къ которымъ и были плотно приросши. Разрьзъ брюшныхъ стьнокъ наль лоннымъ сочлененіеяь, обнаженіе пузыря и освобожденіе правой стьнки его отъ костей таза. Края фистулы освьжены косвенно и соединены 30 швами проникаюпими черезъ мускудатуру до санюистої оболочки. Надъ этимъ первымъ слоемъ нвовъ быль наложенъ еще второй. Со стороны влагалица швы не были наложены, фисту.га зағрылась сама. Спусты четыре неджли получилось изльчченіе.

Авторъ полагаеть, что въ будущемъ прп большихь пузырно-влагалшщныхъ фистулахъ, спиваніе которыхь со стороны влагалища невозножно, вышеописанный способъ можеть огазаться вполнь пригоднымъ.

\title{
А. Брандть.
}

\section{Wertheim. Reinziichtung des Gonococcus Neisser mittels des Plaften- verfahrens (Deutsche medicin. Wochenschrift to 50.1891) 0 nо- лученіи чистой разводки гонококковъ Neisser'a при помощи пла- стиннаго метода.}

Захваченныя нбссколько разъ на платиновой игль частицы триппернаго гноя изъ уретры или изъ содержимаго трубъ при восходящей гоноррењ основательно разбалтываются въ жидкой человьческой кровяной сывороткъ и тогда приготовляю'ся нзъ посльдней два разжнжепія по пзвьстному сиособу. Пробирки съ посьянными частицами ставятся въ водяную баню при $40^{\circ} \mathrm{C}$, и содержимое ихъ смьшивается прпблизительно съ равнымъ объемомь разжиженнаго агара $(20 \%$ агара, $1 \%$ пептона, $0,5 \% \mathrm{NaCl})$ II раз.ІІвается на пластину. Пластины помьщағосея въ влажную камеру пा ставятсл въ термостать при $36-37^{\circ} \mathrm{C}$.

На пластин 's II уже спустя 24 часа выростають колоніш вполнь годныя для перевивки. Мазки, приготовленные изъ этихъ колоній показываютъ, что әти колоніи состоять какъ по формь, таћъ и по отношенію къ окраск'ь изъ типичныхъ гонококковъ. Но самымъ вЊрнымъ доказательствощъ, что колонін на пластинахъ представляють дыйствительно гонококновъ служитъ то обстоятельство, что при перевивк' этихъ колонії на свернутую кровяную сыворотку спустя 48 часовъ развивается чистая культура гонококковъ, которые будучи привиты на слизистую оболочку уретры паралитиковъ пять разъ вызвали характерный трипцеръ, въ отдьляемощъ котораго опять таки констатировалось присутствіе характерныхъ гонококков'ь. 
Такимъ образомъ человьняскаи кровяная сыворотка (изъ плацовты) подъ вліяніень прпбавленіл мясопептоннаго агара (1 ч. сыворотки на 23 ч. МІІА) предсгавляется напоолье выгоднымъ субстратонь для роста гоноröковъ.

\section{А. Брандть.}

83. Coe. Adenoma uteri (Journ. of the Amer. Med. Assoc. July 4, 1891). Аденома матни.

Iрежде ч'ым говорить вообще объ атеномы матки, авторъ пытается влестг н'ькорорю ясность въ запутанную номенклатуру бользней эндометрія. Слизстые полишы, endometritis fungosa, истинная аденома, аденоматозный полипъ, доброкачественная аденома и адено-карцинома, все это описывлется различными авторами, какъ варіаціи истинной аденомы.

Авторъ предлагаеть пазывать истинной злокачественною аденомою только такое новообразованіе, гдй новообразованная аденоматозная ткань не ограничивается одною слизпстою оболочкою матки, но захватываеть и подслизистый пп мышечный слон.

Этимь въ тоже вреил сказано все и объ анатоміи этихъ опухолей.

Такнмъ образонъ «доброкачественная аденома» есть нев'ьрное и неудачное названіе одного изъ видоизмьненій ( variety») истинной аденомы, котоpoe (видоизмьненіе) въ сущности злокачественно и в'ъ клиническомь, и въ анатомпческов смысль. Аденома uteri не тождественна также съ аренокарциномою, но есть начальның и переходный стадій этой посльдней.

Коснувшись вератц'ь литературы маточныхь аденомь, авторъ переходить къ спмптопатологіи, распозпаванію, предсказанію и льченіг этихъ опуходей.

Симптопы этого страдапія, какъ объективные, такь и субъективные, не пають нпкакой точкп опоры для постановки точнаго діагноза. Боли и неправпльныл гровотеченія встрьчаются въ большомъ числь⿱宀㠯 маточныхъ забольваліiі. Еслп ручнымь изльдованіемь п удается констатировать существованіе опухоли, характерь ел всетаки остается намъ неизвъстнымъ. Мы можемъ

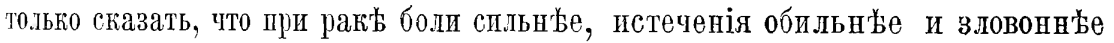
и вахексія наступаеть скор ье, чьым при аденомь.

Отрицательный результатъ микроскопическаго изсльддованія выскобленнаго пзъ матки пе имъеть еще отрицательнаго значенія (при выраженномь рак' матки такое изсльдованіе весьма рьдцко даеть отрнцательный результатъ). Но эта трудность діагноза важна, по мньнію автора, болье въ научномъ, чььъ въ клиническомъ пли хирургическомь отнопеніи. По грайней

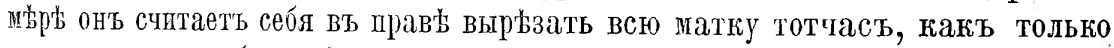
пальпеит и выскаб́ливаніемъ уб́вдился въ сүществованіи разлитой сосочковоп̆ опухопи («diffuse papillary growth»), если даже микроскопь не докажетъ съ положительностью ел злокачественнаго характера.

Итакъ теченіе аденомы длительное и «коварное» («insidious»), т. е. если она п напменуе злокачественна изъ всь̌хь формъ злокатественныхь опухолей, жы не должны создавать себ's иллюзій при виды хорошаго общаго состоянія паціентокь, отсутствіи обильныхъ кровотеченій и т. п. Предоставленная сама себ'́ она рано или поздно ведеть неизбьжно къ смерти оть пстоще- 